\title{
Jaringan Ulama Cirebon Abad ke-19 \\ Sebuah Kajian Berdasarkan Silsilah Nasab dan Sanad
}

\author{
Farihin, S.Hum \\ Aah Syafa'ah, M.Ag \\ Didin Nurul Rosidin, M.A, Ph.D \\ Jurusan Sejarah Peradaban Islam IAIN Syekh Nurjati Cirebon \\ safaah3001@gmail.com
}

\begin{abstract}
ABSTRAK
Jaringan Ulama di Cirebon abad ke-19 merupakan rangkaian mata rantai keilmuan baik berupa sanad tarekat yang ketersambungannya merujuk kepada Rasulullah SAW maupun melalui jalur nasab yang dimiliki oleh para pendiri pesantren di Cirebon yang bermuara kepada Sunan Gunung Jati atau Syekh Syarif Hidayat (1448-1568) sebagai pendiri kerajaan Cirebon pada abad ke-15. Keduanya merupakan entry poin yang dapat menghubungkan ketersambungan ulama atau lebih dikenal sebagai jaringan ulama pada abad sebelum dan sesudah abad ke- 19 tersebut.

Peran Makkah dan Madinah saat itu, terutama pada abad ke-17 dan 18 bahkan memuncak pada abad ke-19, sangat signifikan dalam membentuk rekonsiliasi tasawuf (mistisisme Islam) dan syariat sehingga muncul istilah neo-sufisme. Dan salah satu bentuk dari neo-sufisme ini adalah pengajaran-pengajaran tarekat selain pengajaran Islam lainnya yang lebih berorientasi kepada fikih.

Tarekat Syattariyah kemudian menjadi tarekat yang paling dominan yang diinisiasi oleh para ulama Cirebon yang kemudian membentuk jaringan tersendiri dalam wadah pesantren-pesantren yang tumbuh dan berdiri di Cirebon; selain tentu saja banyak tarekat-tarekat lainnya yang juga berkembang cukup signifikan dengan jumlah pengikut yang cukup massif.

Keberadaan pesantren tidak bisa dilepaskan dari keberadaan halaqa; baik di Makkah atau di al-Azhar Kairo, sampai kemudian pesantren ini mengalami fungsi yang semakin meluas tidak hanya sebagai tempat kajian intelektual dan spiritual semata, tetapi juga sebagai tempat pengkaderan calon ulama-ulama yang kelak menjadi generasi penerus bagi terbentuknya jaringan ulama antar pesantren, khususnya yang berada di wilayah Cirebon.
\end{abstract}

Kata Kunci: Cirebon, Tarekat Syatariyah, sanad, nasab, jaringan ulama 


\section{A. Pendahuluan}

Keresahan Penulis didapatkan berdasarkan hasil penelitian yang dilakukan oleh Didin Nurul Rosidin tentang keberadaan ulama pasca Sunan Gunung Jati yang mengalami keterputusan dan belum terlacak sepenuhnya terutama pada abad ke-18 dan ke-19 di Cirebon.

Sementara pada sisi yang lain penulis banyak menemukan pesantrenpesantren salaf ${ }^{1}$ yang berdiri di wilayah pedalaman Cirebon atau di luar keraton Cirebon, seperti pesantren Babakan Ciwaringin pada tahun 1705 yang didirikan oleh Ki Jatira bin KH. Abdul Latief dari Pamijahan Plumbon Cirebon, pesantren Buntet yang berdiri sekitar tahun 1750 oleh Mbah Muqoyyim, pesantren Balerante sekitar 1774-1784 oleh Syekh Khalifah Raja dan Syekh Romli, pesantren Benda Kerep 1873 oleh KH. Soleh Zamzami dan KH. Anwarudin Kriyani, dan pesantren Gedongan pada tahun 1880 oleh KH. Muhamad Said dan pesantren salaf lainnya. ${ }^{2}$ Perubahan diskursus pesantren kemudian terjadi dengan adanya intervensi VOC terhadap keraton sebagai pusat pengajaran Islam saat itu sehingga kemudian banyak ulama yang melarikan diri ${ }^{3}$ dan membentuk kekuatan-kekuatan baru dalam bentuk pesantren-pesantren yang dibangunnya sehingga memudarkan ketersambungan antar ulama pendiri pesantren tersebut dengan jaringan ulama Cirebon secara utuh; baik secara silsilah nasab ataupun berdasarkan jaringan keilmuan dalam bentuk sanad tarekat.

\footnotetext{
${ }^{1}$ Istilah salaf mengacu kepada jenis pondok pesantren yang masih mempertahankan pengajian kitab kuning ${ }^{2}$ ZamzamiAmin, Sejarah Pesantren Babakan Ciwaringin Cirebon dan Perang Nasional Kedondong 1802-1919. (Bandung Humaniora 2015), hlm. 79-85 dan Td. Sujana, (alih bahasa dan aksara) Kidung Rara Roga (Cirebon Pustaka Keraton Kanoman 24 Oktober 1987) hlm 22. ${ }^{3}$ Salah satunya adalah kepergian Mbah Muqayyim dari keraton Kanoman, saat itu ia sebagai seorang mufti dari Sultan Khaeruddin I (Raja Kanoman), Zamzami Amin, Ibid., hal. 83
} 
Kemudian jaringan ulama Cirebon dengan Timur Tengah baru terbangun kembali ketika Syekh Tolhah ${ }^{4}$ yang berasal dari Desa Trusmi Cirebon menimba ilmu di Makkah dan belajar kepada Ahmad Khatib Sambas ${ }^{5}$ yang terkenal sebagai pendiri Tarekat Qadiriyah wa Nakhsabandiyah. ${ }^{6}$

\section{B. Pembentukan Jaringan Ulama Cirebon Melalui Tarekat}

Tarekat mempunyai akar sejarah yang panjang khususnya di Cirebon dalam hubungan genealogi keilmuan sanad, karena tarekat berfungsi sebagai penyambung sanad keilmuan yang otentik dalam bentuk ijazha. ${ }^{7}$ Sementara ijazha didapatkan ketika seorang murid tarekat melakukan baiat pada tarekat yang dikehendakinya sesuai dengan petunjuk dari seorang mursyid tarekat. Ijazha ini biasanya berbentuk aurad tertentu sesuai dengan jenis tarekat yang diinisiasinya.

Berbicara tentang tarekat di Cirebon, sebagaimana dipaparkan oleh Bambang Irianto bahwa ada sekitar tujuh tarekat yang masih berkembang di Cirebon yaitu Syatariyah, Muhammadiyah, Asrariyah, Ghazaliyah, Jazuliyah, Qadiriyah dan

\footnotetext{
${ }^{4}$ Bambang Irianto, dalam makalahnya, Makna Simbolik Batik Keraton Cirebon, 2009. Syakh Tolhah adalah generasi ke 10 dari Pangeran Cakrabuana melalui Pangeran Trusmi.

${ }^{5}$ Ia dilahirkan di Sambas Kalimantan Barat tahun 1803 dan wafat tahun 1875 di Makkah

${ }^{6}$ Yakni perpaduan antara tarekat Qadiriyah (yang didirikan oleh Syekh 'Abdul Qadir alJailani, 470561 H/1077-1166 M) dan tarekat Naqsyabandiyah (didirikan oleh Syekh Muhammad ibn Muhammad Bahauddin al-Uwaisi al-Bukhari an-Naqsyabandi (717-791 H/1318-1389 M). Bibit Suprapto, Op.Cit., hlm 71.

${ }^{7}$ Perlu diketahui, bahwa ijazha dalam tarekat bukan hanya legalitas ataupun formalitas seseorang dalam menyampaikan ilmu dan ajaran dari sang guru, tapi yang lebih penting dari ijazha sendiri adalah kewenangan atau otoritas seseorang dalam menyampaikan ilmu dan ajaran dari sang guru. Tarekat pada dasarnya berkonsentrasi pada kehidupan rohaniyah, mendekatkan diri kepadaTuhan melalui berbagai kegiatan seperti dzikir dan ibadah lainya. Abdul Basit, (Skripsi), Tarekat Syattariyah (Studi Naskah Ratu Raja Fatimah di Keraton Cirebon.). (Cirebon: Departemen Agama Islam Republik Indonesia IAIN Syekh Nujati Cirebon 2014). hlm. 18.
} 
Nakhsabandiyah, bahkan ada tarekat Tijaniyah $^{8}$ yang berkembang di Buntet Pesantren. ${ }^{9}$

Menurut Agus Sunyoto, tarekat Syatariyah adalah tarekat yang pertama dibawa oleh Syekh Idofi Mahdi atau Syekh Dzatul Kahfi atau Syekh Nurjati ke Cirebon. Dan dengan melihat tahun wafatnya Syekh Abdullah Syatar pada $1485^{10}$ kemudian dihubungkan dengan kedatangan Syekh Dzatul Kahfi pada tahun 1420, penulis berkesimpulan bahwa sangat masuk akal jika Tarekat Syattariyah dibawa oleh Syekh Dzatul Kahfi atau Syekh Nurjati tersebut dan dibawanya ke Cirebon.

Bahkan, informasi yang ada di dalam Naskah Tarekat milik Elang Panji dari Mertasinga, ada 42 tarekat yang berkembang di Cirebon yaitu sebagai berikut: 1 . Naksabandiyah, 2. Qadiriyah, 3. Syadziliyah, 4. Rifa'iyah, 5. Ahmadiyah, 6. Akbariyah, 7. Mauludiyah, 8. Kubrowiyah, 9. Sahrawardiyah, 10. Khalwatiyah, 11. Jalutiyah, 12. Bukrasiyah, 13. Ghazaliyah, 14. Rumiyah, 15. Sa'diyah, 16. Sa'baniyah, 17. Kasyafiyah, 18. Hazawiyah, 19. Biramiyah, 20. Asyakiyah, 21. Jitsniyah, 22. Bakriyah, 23. Umariyah, 24. Usmaniyah, 25. Ulwiyah, 26. Abasiyah, 27. Zaenabiyah, 28. Isawiyah, 29. Maghrabiyah, 30. Buhuriyah, 31. Hadadiyah, 32.

\footnotetext{
${ }^{8}$ Terkait keberadaan tarekat Tijaniyah di Buntet pesantren, terdapat peranan lain dari sosok selain Kyai Abbas yaitu Kyai Anas, adik dari Kyai Abbas. Ia menekuni dunia tarekat atas kepergiannya beribadah haji ke Makkah pada tahun 1924. Ia mempelajari kitab-kitab pegangan tarekat Tijaniyah dari gurunya Syekh Alfa Hasyim selama 3 tahun. Kitab-kitab tersebut adalah Jawahir al-Ma'ani, Rimah, Bughyat al-Mustafid. Syekh Alfa Hasyim sendiri merupakan muqaddam Tijani ke-5; dengan urutan muqaddam sebagai berikut: Muhammad Alfa Hasyim dari Syekh al-Hajj al-Sa'id dari Syekh Amr bin Sa'id al-Futi dari Muhamad al-Ghala dari Ahmad al-Tijani dari Rasulullah SAW. Eli Fatihah, Studi Living Qur'an: Penggunaan al-Qur'an sebagai Media Istikharah di Pesantren al-Ishlah Sidamulya Astanajapura Cirebon, 2017, hal. 28

${ }^{9}$ Bambang Irianto Teks Klasik Keagamaan Sulawesi dan Cirebon, Jakarta: Puslitbang Lektur dan Khazanah Keagamaan Badan Litbang dan Diklat Kementrian Agama RI 2013, hal.312

${ }^{10}$ Mahrus El-Mawa http://syattariyah.blogspot .co.id/2012/05 diunduh pada 3 Juni 2016
} 
Ghaibiyah, 34. Hadhoriyah, 35. Syatariyah, 36. Bayumiyah, 37. Malamiyah, 38. Firdausiyah, 39. Matbuliyah, 40. Bayumiyah, 41. Sunbulliyah, 42. Uwesiyah. ${ }^{11}$

Jika sumber di atas autentik, maka benar apa yang dikatakan oleh Mahrus el-Mawa, bahwa Cirebon sebagai Melting Pot Islam Nusantara melalui tarekat-tarekat tersebut di atas adalah benar.

Pada abad ke-15-18 tarekat menjadi mainstream yang banyak diajarkan oleh para guru sufi, karena pola ajaran yang dimiliki oleh ajaran tasawuf atau tarekat ini dianggap lebih kultural dalam upaya Islamisasi di Indonesia, khususnya di Cirebon. Hal ini semakin memperjelas peran tarekat yang berfungsi tidak hanya sebagai penyambung sanad hubungan guru (mursyid tarekat) dengan murid, akan tetapi berfungsi juga sebagai penopang Islam sebagai sebuah ajaran yang lebih kultural dan bersifat indigenous.

Salah satu tarekat yang menjadi sebab terbentuknya jaringan ulama Cirebon adalah tarekat Syattariyah melalui beberapa mursyid seperti Kiai Asy'ari Kaliwungu yang mempunyai murid KH. Anwarudin Kriyani, Syekh Abdullah bin Abdul Kohar yang mengajarkan Syattariyah kepada Haji Muhamad Mu'tasim Cirebon, dan melalui Syekh Abdul Muhyi Pamijahan yang merupakan murid dari Abdur Rauf as-Sinkili (1615-1693) ${ }^{12}$ yang mengajarkan tarekat ini kepada Mbah Muqayyim. Para mursyid tarekat inilah yang pada saatnya menjadi motor penggerak terbentuknya jaringan ulama Cirebon sekaligus merupakan bentuk

\footnotetext{
${ }^{11}$ Menurut Bambang Irianto, Naskah Tarekat milik Elang Panji bernomor Kode Digital 211_EPJ005_0042, naskah tersebut dianggap kurang valid, karena menyebutkan tarekat bayumiyah sebanyak dua kali dan tiddak menyebutkan tarekat Asrariyah dan Muhamadiyah, padahal kedua tarekat ini masih eksis sampe sekarang. Bahkan dalam Naskah Kuningan,Sunan Gunung Jati mempelajari Tarekat Muhamadiyah. Ahmad Rahman dkk, Teks Klasik Keagamaan Sulawesi dan Cirebon (Jakarta : Puslitbang Lektur dan Khazanah Keagamaan Badan Litbang dan Diklat Kementrian Agama RI 2013) hlm 309-310.

${ }^{12}$ Mahrus el-Mawa,Melting Pot Islam Nusantara Melalui Tarekat : Studi Kasus Silsilah Tarekat Syatariyah di Cirebon,Pdf., hal: 3-12.
} 
perlawanan terhadap kolonial, sehingga fihak kolonial sangat mewaspadai gerak gerik para ulama tarekat tersebut. ${ }^{13}$

Selain tarekat, faktor lain yang mendukung terbentuknya jaringan ulama Cirebon adalah melalui aktivitas ibadah haji ${ }^{14}$ dan dengan dibukanya terusan Suez ${ }^{15}$ pada tahun 1869 .

\section{Cirebon Sebagai Pusat Kajian Intelektual dan Spiritual}

Cirebon sebagai pusat kajian intelektual dalam penyebaran agama Islam sudah dimulai sejak kedatangan Syekh Dzatul Kahfi atau Syekh Nurjati. Ketika itu Dzatul Kahfi diberi tempat oleh Syahbandar Ki Jumajan Jati di Bukit Amparan Jati. Dzatul Kahfi kemudian mendirikan pesantren bernama Pesantren Amparan Jati pada 1420. Pendirian pesantren ini tidak bisa dilepaskan dari bantuan finansial yang dilakukan oleh istrinya sendiri bernama Khadijah yang tidak lain adalah cucu dari Brata Legawa atau Haji Purwa Galuh.

Keberadaan pesantren Amparan jati itu semakin dikenali oleh penduduk setempat sehingga menarik banyak santri untuk belajar ilmu agama Islam di dalamnya termasuk dua putra Prabu Siliwangi yaitu Walangsungsang dan Rara

\footnotetext{
${ }^{13}$ Dalam kolonial Arsip di Nederland, tercatat perlawanan bangsa Indonesia dalam tempo satu abad 1800-1900 terjadi perlawanan 112 kali, yang dimotori oleh para Ulama, guru tarekat dan Haji. Hal ini membuktikan bahwa dalam satu tahun terjadi 2-3 kali perlawanan. Agus Sunyoto dalam Buletin Harokah: Melacak Paham Gerakan Islam Trans Nasional, Lirboyo Jawa Timur, Jamiyyah Syubbaniyyah Pusat keluarga Besar Santri Jawa Barat, 2014, hlm. 20
}

${ }^{14}$ Zulfa Ahmad, Perhajian di Abad 19 dan Awal Abad 20 Serta Pengaruhnya Tehaddap Pendidikan di Indonesia, (Pdf) hlm 114.e-journal.iainjambi.ac.id. diunduh pada minggu 4 Juni 2017 pukul 22.00. karena persoalan haji ini menjadi fenomena tersendiri karena perjalanan haji dijadikan sebuah momentum untuk membangun jaringan baik itu politik, dagang dan keagamaan.

\footnotetext{
${ }^{15}$ Terusan suez terletak di sebelah barat semenanjung Sinai, merupakan terusan kapal sepanjang 163 $\mathrm{km}$ yang terletak di Mesir yang berfungsi menghubungkan pelabuhan Sa'id di laut tengah dengan Suez di laut merah
} 
Santang. Sepeninggal Syekh Nurjati pesantren ini kemudian diteruskan oleh Syarif Hidayat dan Ibundanya yaitu Syarifah Mudaim.

Menurut T.D Sujana, meskipun Syarif Hidayat berposisi sebagai raja, akan tetapi ia lebih disibukan dengan pengembangan agama Islam dengan melakukan kajian-kajian Islam di masjid-masjid yang ada di wilayah Cirebon dan sekitarnya. Pusat kajian Islam pada waktu itu berada di Nurgiri Saptarengga atau yang sekarang dikenal sebagai Astana Gunung Sembung.

Masih menurut T.D. Sujana, pada perkembanganya, Pengguron Nurgiri Saptarengga menjadi pesantren yang didominasi oleh perempuan dan yang mengelola pengguron tersebut adalah Nyai Syarifah Mudaim dengan sebutan Sayyidatin Panatagama yang tidak lain adalah ibu dari Syarif Hidayat sendiri. Adapun Syarif Hidayat sendiri lebih suka dakwah keliling dari satu tempat ke tempat yang lain. Jika sumber di atas otentik, maka sudah jelas bahwa pesantren perempuan pertama di Cirebon bukanlah di Panguragan, sebagaimana yang ditulis dalam Skripsi Nurhasanah, melainkan Nur Giri Saptarengga yang dikelola oleh Syarifah Mudaim itulah yang menjadi pesantren perempuan pertama di Cirebon.

Pada masa Syarif Hidayat, Cirebon dijadikan sebagai pusat penyebaran agama Islam di Tanah Sunda. ${ }^{16}$ Hal ini menunjukan bahwa Cirebon menjadi pusat kajian keislaman yang banyak dikunjungi santri dari berbagai daerah. Syarif Hidayat sendiri, sejak tahun 1528 pasca perang Cirebon dan Raja Galuh memusatkan pehatiannya pada usaha penyebaran agama Islam sampai pada wafatnya tahun 1568.

Selain pesantren, berdiri pula mesjid-mesjid sebagai pelengkap sarana pendidikan Islam yang dapat dipergunakan sebagai tempat dilakukannya kajiankajian keislaman dan juga sebagai tempat bermusyawarah.

\footnotetext{
${ }^{16}$ Maman Suriaman, Perkembangan Pesantren di Wilayah Cirebon dalam Perspektif Sejarah Pendidikan Nasional, Makalah disajikan dalam acara Gotrasawala pada 24 Januari 1990, hlm: 4
} 
Sebelum berdirinya Masjid Sang Cipta Rasa pada 1480, Tajug Pejalagrahan yang didirikan pada masa Pangeran Walangsungsang sempat berfungsi sebagai tempat kajian agama Islam dan basis gerakan dakwah Islamisasi di Cirebon, namun setelah Sang Cipta Rasa berdiri, pusat kajian Islam beralih ke Masjid Sang Cipta Rasa tersebut. Sebenarnya, Sang Cipta Rasa bukanlah satu-satunya masjid yang menjadi tempat kajian Islam, sebelumnya sudah berdiri Masjid Panjunan (1480),Tajug Agumg Kejaksan (1479/1480), Masjid Trusmi (1481), Masjid Dog Jumeneng (1542), dan masjid kramat Depok (sekitar awal abad 15). ${ }^{17}$

Cirebon sebagai pusat kajian keilmuan dan penyebaran agama Islam diperkuat dengan sebutan Cirebon sebagai Puser Bumi (Bujal Buwana) pada masa pemerintahan Panembaan Ratu I (Pangeran Mas) yaitu cicit Syarif Hidayat atau cucu dari Fadilah Khan yang tampil sebagai raja sekaligus seorang pertapa karena seluruh hidupnya diabdikan untuk kepentingan syiar agama Islam. Ia pernah mesantren di Pajang selama 16 tahun, beristri Ratu Lampok Angroros (Putri Sultan Pajang) dan berguru kepada Sultan Hadiwijaya Jaka Tingkir. ${ }^{18}$

Setelah Panembahan Ratu I wafat (1649), Kerajaan Cirebon dipimpin oleh Pangeran Karim, bergelar Panembahan Girilaya (1601-1662). Pada masa Pangeran Karim, Cirebon masih menjadi pusat kajian keilmuan. Hal ini dapat dibuktikan

\footnotetext{
${ }^{17}$ Yulia Eka Puttri dkk, Masjid Kuno Cirebon, Bandung: Dinas Pariwisata dan Kebudayan Provinsi Jawa Barat, 2015, hlm: 52

${ }^{18}$ Pada masa Panembahan Ratu I bisa dikatakan sebagai masa keemasan kedua (golden age two) setelah masa Sunan Gunung Jati. Pada masa inilah banyaklahir karya sastrayang berkembang pesat. Kerajaan Cirebon dianugrahi seorang Pujangga yang banyak melahirkan karya yang luar biasa. Salah satunyaadalah Pangeran Losari. Ia adalah seorang ulama ahli tasawuf, yang melahirkan karya antara lain, Purwaka Smesta Buwana 17 jilid, dan Pustaka Dwipantara Purwa (1547).Selain Pangeran Losari, ulama lain yang membuat karya pada masa panembahan Ratu I adalah Pangeran Manis, Pangeran Pulosarendan, Panembahan Wirasuta Gebang (adik Pangeran Losari), Pangeran Sedang Gayam (ayah PanembahanGirilaya), Pangeran Arya Kidul (kakak Pangeran Sedang Gayam) dan masih banyak tokoh ulama yang lainnya.
} 
dengan keberadaan ulama yang sangat dihormati. Ilmu agama menjadi sesuatu yang sangat dipuji dan dinomersatukan melebihi apapun. Di Cirebon banyak sekali orang yang berguru dan menuntut ilmu. Ilmu fiqih dan ilmu tasawuf diajarkan di masjid-masjid. Banyak orang berbai'at ${ }^{19}$ tasawuf guna menemukan kesejatian hidup. Para Ki Gede pun berdatangan memohon diajarkan ilmu sejati dan para santri pun dijamin pangannya. ${ }^{20}$

\section{Jaringan Ulama Cirebon abad ke-19}

Secara nasab dan sanad para ulama keturunan Sunan Gunung Jati yang membangun jaringan keilmuan dengan Cirebon tersebar di berbagai wilayah, takterkecuali di Makkah dan Madinah (Haramayn). Adapun ulama-ulama yang belajar di Haramayn dan membangun jaringan keilmuan sanad dengan ulama Cirebon sekaligus menjadi guru utama ulama-ulama Nusantara antara lain Syekh Nawawi al-Bantani, Ahmad Khatib Sambas (w.1875), Syekh Dawud al-Fatani Thailan Selatan, Syekh Mahfudz at-Termasi, Syekh Abdul Karim al-Bantani, Syekhana Khalil Bangkalan Madura, Ahmad Khatib al-Minangkabawi, KH. Hasyim Asy'ari, KH.Abdul Karim Lirboyo, Syekh Muhammad Amin bin Ahmad Ridwan al-Madani atau biasa disebut Syekh Dalail Khairat, Syekh Said Ali alYamani, Syekh Husen al-Habsyi dan beberapa ulama lainnya.

Dalam geneologi nasab, ulama-ulama Cirebon hampir semua bersambung nasabnya pada Sunan Gunung Jati. Sosok KH. Abbas (1879-1946) Buntet misalnya, ia merupakan ulama keturunan Sunan Gunung Jati. Ayahnya bernama KH. Abdul Jamil bin Kiai Raden Muta'ad bin KH. Raden Nurudin bin Raden

\footnotetext{
${ }^{19}$ Bai'at artinya janji atau sumpah setia

${ }^{20}$ Cirebon sebagai pusat kajian keilmuan, masih tetap bertahan sampai era Pangeran Karim atau Panembahan Girilaya. Meskipun dimasa Pangeran Karim Cirebon tidak sejaya pada masa Panembahan Ratu dalam hal keilmuan, akan tetapi dimasa Pangeran Karim, ilmu masih dijunjung tinggi dan para santri dan llama masih dimuliakan. Bambang Irianto dan Ki Tarka Sutarahardja, Sejarah Cirebon, Naskah Keraton Kacirebonan alih bahasa dan aksara, Yogyakarta: CV. Budi Utama, hlm: 87-88
} 
Muridin bin Pangeran Punjul bin Pangeran Kebon Agung bin Pangeran Sutajaya Seda Ing Tambak bin Pangeran Natamanggala bin Pangeran Sutajaya Seda Ing Demung bin Pangeran Wirasuta Jaya Wira Upas Gebang bin Pangeran Sedang Kemuning bin Pangeran Muhammad Arifin bin Syarif Hidayatullah. Versi yang lain dari jalur Panembahan Girilaya bin Pangeran Sedang Gayam bin Panembahan Ratu I bin Pangeran Sedang Kemuning bin Pangeran Muhammad Arifin bin Syarif Hidayatullah.

Kyai Abbas putra dari KH. Abdul Jamil belajar dasar-dasar ilmu agama Islam kepada bapaknya, baru kemudian ia melanjutkan pendidikan pesantrennya kepada Kyai Nasuha di pesantren Sukanasari Plered Cirebon dan seterusnya kepada Kyai Hasan di Pesantren Jatisari untuk selanjutnya kepada Kyai Ubaidah Tegal Jawa Tengah. ${ }^{21}$

Pendidikan pesantrennya terus berlanjut sampai ke Pesantren Tebu Ireng Jombang yang diasuh oleh Kyai Hasyim Asy'ari. Di Tebu Ireng, Kyai Abbas bertemu dengan Kyai Wahab Hasbullah (1888-1971)dan Kyai Abdul Karim Lirboyo. Mereka bertiga bersahabat baik.Selain bersahabat dengan keduanya, Kyai Abbas juga bersahabat dengan Kyai Amin Babakan, dengan Kyai Jauhar Arifin Balerante, dengan Kyai Syatori Arjawinangun dan dengan Kyai Samsuri Wanantara dan para kyai lainnya. ${ }^{22}$

\footnotetext{
${ }^{21}$ Choirul Fuad dkk, Ensiklopedi Pemuka Agama Nusantara, Jakarta: Puslitbang Lektur Dan Khazanah Keagamaan Badan Litbang Dan Diklat Kementrian Agama RI, 2016, hlm. 14-16

${ }^{22}$ Selain sahabat-sahabat yang tersebut di atas, sahabat lain yang dimiliki oleh Kyai Abbas Buntet Cirebon adalah denganKH. Dalhar Watucongol (1870-1959), KH. Bisyri Sansuri Pati (1886-1980), KH. Ma'sum Lasem (1870-1971), KH. Asnawi Kudus (1861-1959) dan ulama-ulama yang lainnya.Dalam Munawar Aziz, Pahlawan Santri, Tulang Punggung Pergerakan Nasional, Ciputat Tanggerang: Pustaka Kompas 2016, hlm, 38-158
} 
Meskipun KH. Abbas muda keilmuannya sudah cukup tinggi, namun ia belum puas dengan keilmuan yang dimilikinya tersebut, sehingga ia pun belajar ke Makkah dan berguru kepada Syekh Mahfudz Termas Pacitan yang juga guru dari KH. Hasyim Asy'ari.

Selama di Makkah, ia bermukim bersama KH. Bakir Yogyakarta, KH. Abdillah Surabaya dan KH.Wahab Hasbullah Jombang (1888-1971) dan sebagai santri yang matang, KH. Abbas kemudian ditugasi untuk mengajar santri-santri Indonesia yang ada di Makkah, salah satunya adalah KH. Cholil Balerante.

Ketika kembali ke tanah air, Kyai Abbas memperkenalkan tarekat Tijaniyah- selain tentu saja ia adalah seorang mursyid tarekat Syatariyah- di Buntet Pesantren. Persentuhan tarekat Tijaniyah dengan Syattariyah di Buntet Pesantren ini kemudian menjadi unik dengan lebih banyak diwarnai oleh tarekat Tijaniyah sampai dengan sekarang.

Sementara tarekat Syattariyah berkembang cukup pesat di Benda Kerep oleh Kyai Soleh Zamzami yang tidak lain adalah paman dari Kyai Abbas. Di Benda Kerep tarekat Syattariyah kemudian dikembangkan oleh dua ulama putra Kyai Soleh Zamzami yakni Kyai Muslim dan Kyai Abu Bakar.

Selain Buntet dan Benda Kerep, tarekat Syatariyah juga berkembang di Pesantren Balerante yang didirikan oleh Syekh Romli. Dari sisi genealogi syekh Romli adalah keturunan dari Kiai Nursijan bin Buyut Pantar bin Buyut Dasim bin Buyut Kamal bin Pangeran Sidik Jayanegara bin Ratu Mas Jangkep bin Syekh Pasiraga bin Pangeran Ramangkurat bin Sunan Gunung Jati dengan istrinya Nyai Gede Babadan. ${ }^{23}$

\footnotetext{
${ }^{23}$ merupakanistri pertama Sunan Gunung Jati. Ia merupakan anak dari Ki Gede Babadan. Babadan menurut Dasuki terletak di Indramayu termasuk wilayah Sindang tetapi menurut naskah Kuningan Babadan ini terletak di Banen Girang. Sumber https://www.historyofcirebon.id.2018/02. Diunduh $\operatorname{tgl} 9$ Juni 2019
} 
Selain di tiga pesantren yang ada di Cirebon, Tarekat Syattariyah juga berkembang di Kuningan, tepatnya di Pesantren Lengkong yang diasuh oleh KH. Hasan Maulani (w.1874), di Pesantren Ciwedus ${ }^{24}$ yang diasuh oleh KH. Ahmad Sobari (w.1916) dan di Pesantren al-Mutawally yang diasuh oleh Abah Mutawally. 25

Dalam hal ini, tarekat Syattariyah menjadi penghubung terbentuknya jaringan ulama Cirebon dengan ulama-ulama Kuningan seperti tersebut di atas. Tarekat betul-betul menjadi tali ketersambungan antara ulama yang satu dengan ulama

\footnotetext{
${ }^{24}$ Pesantren Ciwedus Kuningan didirikan oleh KH. Kalamudin, ulama asal Banten pada wal abad ke-18. KH. Ahmad Sobari adalah generasi keempat yang meneruskan Pesantren Ciwedus setelah KH. Kalamudin, KH. Syu'eb (menantu KH. Kalamudin) dan KH. Adzro'i. Pada masa KH. Ahmad Sobari inilah Pesantren Ciwedus berkembang pesat dan banyak melahirkan ulama-ulama seperti KH. Habib Abdurohman di Semarang, Habib Jagasatru di Cirebon, Kyai Sanusi di Babakan Ciwaringin Cirebon, Kyai Syatibi dan KH. Hidayat di Cikijing-Majalengka, KH. Zaenal Mustofa di daerah Kandang Sapi-Cianjur, KH. Abdul Halim (pendiri PUI) di Majalengka, KH. Mutawally, KH. Mahfudz di Cilimus Kuningan, KH. Sudjai di Gudang- Tasikmalaya, KH.Hambali di Ciamis, KH. Syamsuri Baedowi di Tebuireng- Jawa Timur, KH. Ilyas di daerah Cibeunteur (Banjar) dan lainlain. Didin Nugraha, http://tnnujabar.or.id/jejak-pesantren-tatar-sunda-pra-kemerdekaankabupatenkuningan-dan-majalengka/ diunduh pada 8 Januari 2019 pukul 10.30, lihat juga hasil penelitiam berjudul Sejarah Perkembangan Islam Di Jawa Barat Pimpinan Prof. Dr. Hj. Nina H. Lubis, M. S
}

${ }^{25}$ Abah Mutawally atau KH. Siradjur Rosyidin (1819-1953) diceritakan pernah belajar kepada KH. Soleh Zamzami dan KH. Anwarudin Kriyani. Dalam pengembaraan intelektualnya, selain belajar di Pesantren Benda Kerep, Abah Mutawally juga belajar di Pesantren Ciwedus, Madura dan di Timur Tengah. Abah Mutawally lahir pada 1819 atau 1824, maka kemungkinan ia belajar kepada ayah atau mungkin kakek dari KH. Ahmad Sobari Besar kemungkinan Abah Mutawally juga bertemu degan KH. Hasan Maulani Lengkong yang juga merupakan pengamal tarekat Syattariyah dari jalur KH. Mas Muhammad Arjain, Penghulu Keraton Kanoman Cirebon.Dalam Hamdan, Peran Kyai Haji Siradjur Rosyidin (Abah Mutawally) 1819-1953 Dalam Menyebarkan Dakwah Islam Di Kuningan, Skripsi, Cirebon: Jurusan Sejarah Peradaban Islam IAIN Syekh Nurjati Cirebon, 2017, hlm 8- 24 
yang lain, baik itu secara sanad keilmuan atau karena hubungan persahabatan sesama ulama penganut tarekat Syattariyah tersebut.

\section{E. Silsilah Nasab Ulama-Ulama Cirebon Dari Sunan Gunung Jati}

Silsilah berikut ini adalah gambaran adanya ketersambungan dari sisi nasab antara Sunan Gunung Jati dengan para pendiri pesantren di wilayah Cirebon sebagai berikut:

\section{Silsilah Nasab Ulama-ulama Cirebon Dari Sunan Gunung Jati}

\section{Syekh Maulana Syarif Hidayatullah (Sunan Gunung Jati)}

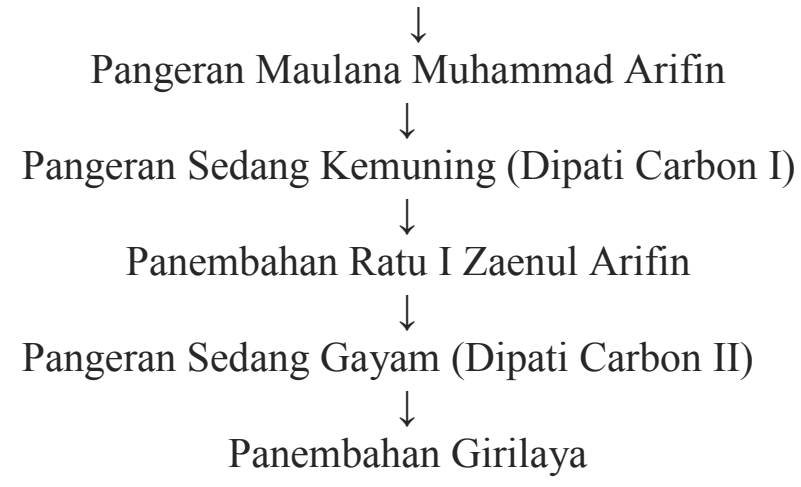

2. Panembahan Girilaya berputra antara lain : Pangeran Natadiningrat, Pangeran Samsudin Martawijaya (Sultan Sepuh I) dan Pangeran Badridin Kartawijaya (Sultan Anom I)

3. Silsilah nasab Pangeran Natadiningrat

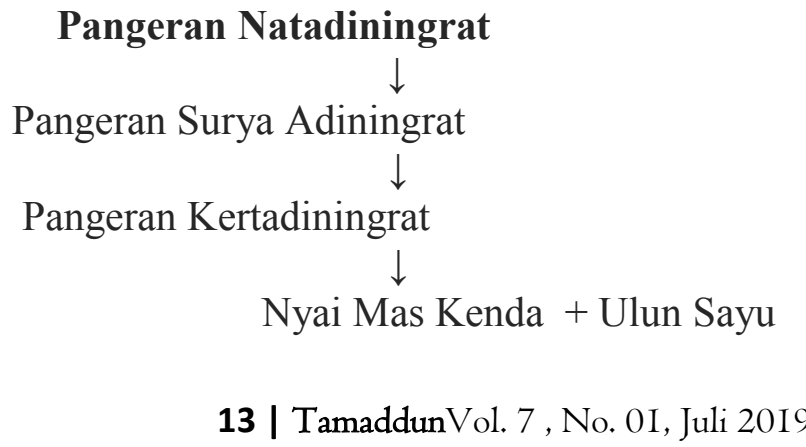




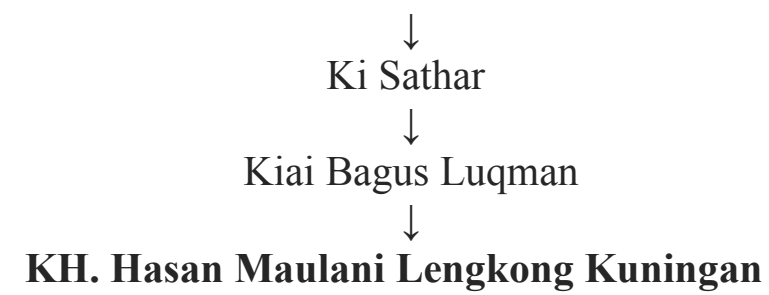

(Pendiri Pesantren Lengkong)

4. Silsilah nasab keturunan Pangeran Badridin Kartawijaya (Sultan Anom I)

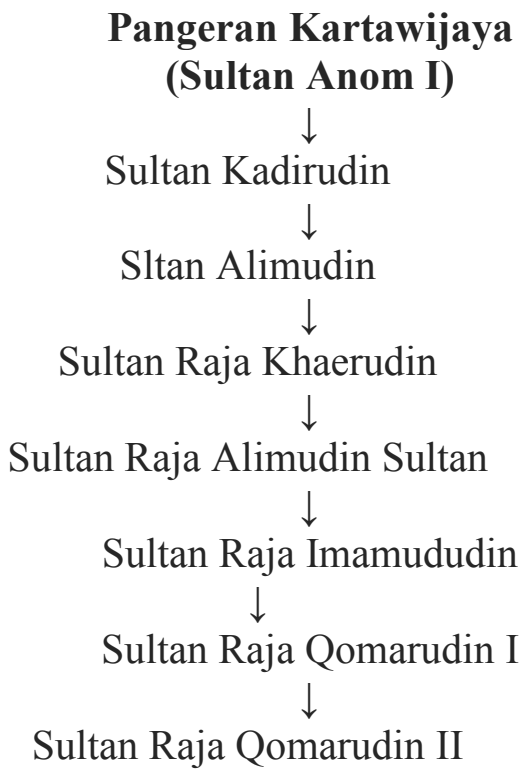

5. Sultan Raja Qomarudin II berputra antara lain : Kiai Abdullah dan Syekh Hasanudin

a. Silsilah keturunan Kiai Abdullah

Kiai Abdullah

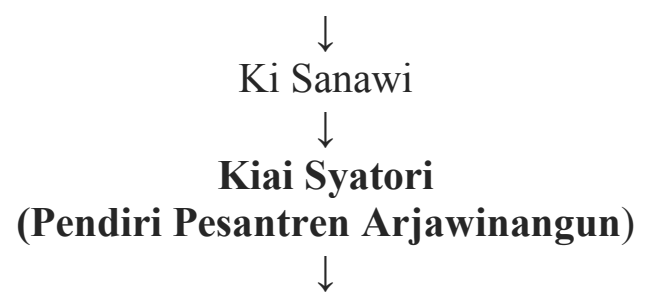

14 | TamaddunVol. 7 , No. OI, Juli 2019 


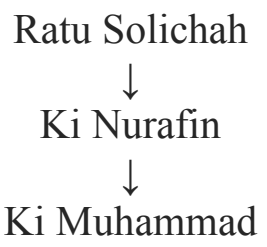

b. Silsilah keturunan Syekh Hasanudin

Syekh Hasanudin

\author{
Nyai Madrawi + Kiai Jalil
}

Pernikahan Kiai Jalil dan Nyai Madrawi binti Syekh Hasanudin berputra antara lain Kiai Harun (Pendiri Pesantren Kempek Cirebon) dan Ki Qunawi Silsilah keturunan Ki Qunawi

\author{
Ki Qunawi \\ Kiai Hasbullah \\ (Pendiri Pesantrn Winong Palimanan Cirebon) \\ KH. Mustahdi Hasbullah
}

6. Silsilah nasab keturunan Pangeran Martawijaya (Sultan Sepuh I)

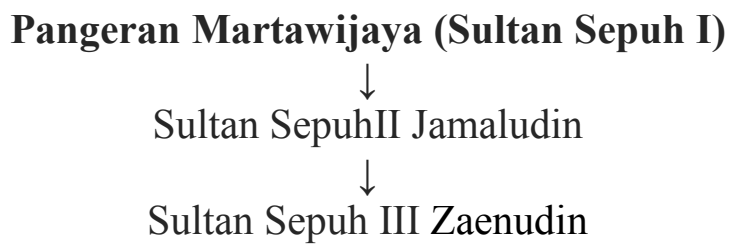

a. Sultan Sepuh III Zaenudin berputra antara lain : Sultan Sepuh IVZaenudinAmir Sena dan Pangeran Arya Natas Angin (pendiri Masjid Keramat Megu Plered) 
b. Silsilah nasab keturunan Sultan Sepuh IVZaenudin Amir Sena, berputra antara lain Syekh Idrus dan Kiai Sulaiman Jamaludin (pendiri Pesantren Gontor Ponorogo Jawa Timur)

1). Sultan Sepuh IVZaenudin Amir Sena

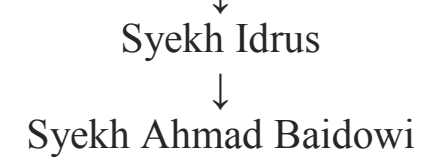

\author{
Nyai Quraitin \\ Nyai Maria + Kiai Arsyad \\ $\downarrow$ \\ KH. Amin Sepuh Babakan Ciwaringin \\ 2). Sultan Sepuh IVZaenudin Amir Sena \\ $\downarrow$ \\ Kiai Sulaiman Jamaludin \\ (Pendiri Pesantren Gontor Ponorogo Jawa Timur)
}

c. Silsilah nasab keturunanPangeran Arya Natas Angin (pendiri Masjid

Keramat Megu Plered Cirebon) berputra antara lain, Pangeran

Alimudin Martakamuning (Pangeran Sapu Angin (Buyut Amad) dan

Pangeran Asyrofudin Hadiningrat

Pangeran Arya Natas Angin

1). Pangeran Alimudin Martakamuning (Pangeran Sapu Angin (Buyut Amad) 


\title{
Pangeran Alimudin Martakamuning (Pangeran Sapu Angin (Buyut
} Amad)berputra antara lain :

(1). Raden Muhammad (Buyut Amad bocah Buntet Astana JapuraCirebon)

(2). Nyai Syarifah Benda Kerep

(3). Raden Baalawi Gempol Lebak Ciwaringin Cirebon

(4). Raden Maulangi Citotok Kesal Palimanan Cirebon

(5). Raden Maulani Penawuwan Kedung Bunder Palimanan Cirebon

\author{
Pangeran Arya Natas Angin \\ 2). Pangeran Asyrofudin Hadiningrat \\ (Pendiri Pesantren Conggeang Sumedang)
}

\section{F. Silsilah Sanad Tarekat Syattariyah Ulama-Ulama Cirebon}

Silsilah berikut ini menggambarkan adanya ketersambungan sanad tarekat Syatariyah antara ulama-ulama di Cirebon sampai kepada Rasulullah SAW, sebagai berikut:

\section{Silsilah Sanad Ulama Tarekat Syattariyah Abad 19}

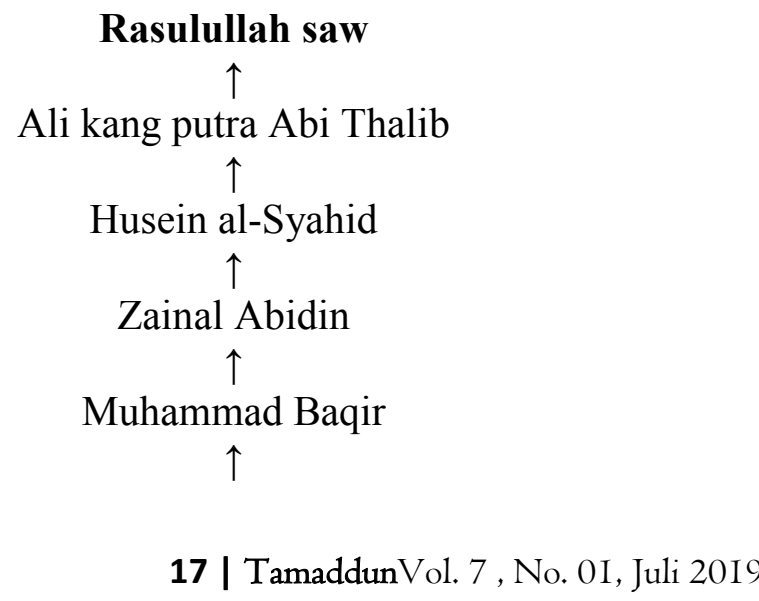


Ja ${ }^{e e} f a r$ al-Sidiq

$\uparrow$

Sultan Arifin Abi Yazid al-Bistami

$\uparrow$

Muhammad Magrib

Arabi Yazid al-,„Isyqi

$\uparrow$

Abu Mugafir Maulana Ihram Tusi

Abi Hasani Harqani

Hadaqili Madri al-Nahrini

$\uparrow$

Muhammad 'Asyiq

$\uparrow$

Muhammad 'Arif

Hidayat Allah Sarmusun

$\uparrow$
Hasur
$\uparrow$
Muhammad Gaus kang putra Hatib al-Din
$\uparrow$
Wajih al-Din
$\uparrow$
Sibgat Allah kang putra Sayyid Ruh Allah

$\uparrow$

Sayyidina Abi Muwahid Abd Allah Ahmad kang putra Abbas

Syaikh Ahmad kang putra Muhammad ing Madina, Syaikh Ahmad Qasyasi $\uparrow$

Syaikh Abd al-Rauf kang putra Ali kang bangsa Fansuri

$\uparrow$

Syaikh Abd al-Muhyi Safarwadi 
Syaikh Abd al-Muhyi Safarwadi mempunyai murid antara lain: KH. M. Asyik Pamijahan, Syekh H. Abdullah Saparwadi dan Pangeran Dalem Bojong

\title{
1. Silsilah sanad guru-murid Syekh H. Abdullah Saparwadi
}

\author{
Syekh H. Abdullah Saparwadi \\ $\uparrow$ \\ Syekh Hasanudin Saparwadi \\ $\uparrow$ \\ KH. Mumammad Saleh Kertabasuki Cirebon \\ KH. Mas Muhammad Arjain Kanoman \\ Pangeran Harya Kacirebonan \\ $\uparrow$ \\ Pangeran Padmaningrat \\ $\uparrow$ \\ Pangeran Muhammad Ismail Ernawa Kacirebonan \\ Pangeran Abdullah Cirebon
}

a. KH. Mas Muhammad Arjain Kanoman b. Pangeran Harya Kacirebonan

Ratu Raja Fatimah Kiai Bidin Cilimus

c.KH. Mumammad Saleh Kertabasuki Cirebon

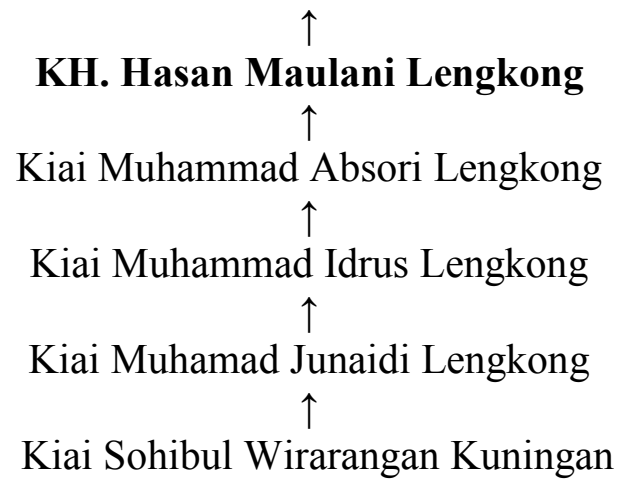

19 | TamaddunVol. 7 , No. OI, Juli 2019 


\title{
Silsilah sanad guru-murid Pangeran Dalem Bojong
}

\author{
Pangeran Dalem Bojong \\ $\uparrow$ \\ Kiai Bagus \\ $\uparrow$ \\ Mbah Muqoyyim \\ $\uparrow$ \\ Kiai Bagus Wanantara \\ Nyimas Ayu Alimah
}

2. Silsilah sanad guru-murid KH. M. Asyik Pamijahan

\author{
KH. M. Asyik Pamijahan \\ $\uparrow$ \\ Nyai Hakim Matram \\ $\uparrow$ \\ Kiai M. Giriloyo \\ $\uparrow$ \\ Kiai M. Giriloyo \\ $\uparrow$ \\ Pangeran Raja Kanoman
}

20 | TamaddunVol. 7 , No. OI, Juli 2019 
Gambaran lain tentang silsilah sanad tarekat Qadiriyah wa Naqshabandiyah yang menghubungkan ulama Cirebon dengan Rasulullah SAW, sebagai berikut:

\section{H. Hubungan Sanad Keilmuan (Guru-Murid) Ulama Timur Tengah, Nusantara dan Cirebon}

Adapun silsilah Sanad Keilmuan Ulama Timur Tengah, Nusantara dan Cirebon menurut keterangan KH. Said Aqil Siraj sebagai berikut:

Sayyidina Rasulullah Muhammad SAW

$$
\uparrow
$$

Sayyidina Ali bin Abi Thalib Kw.

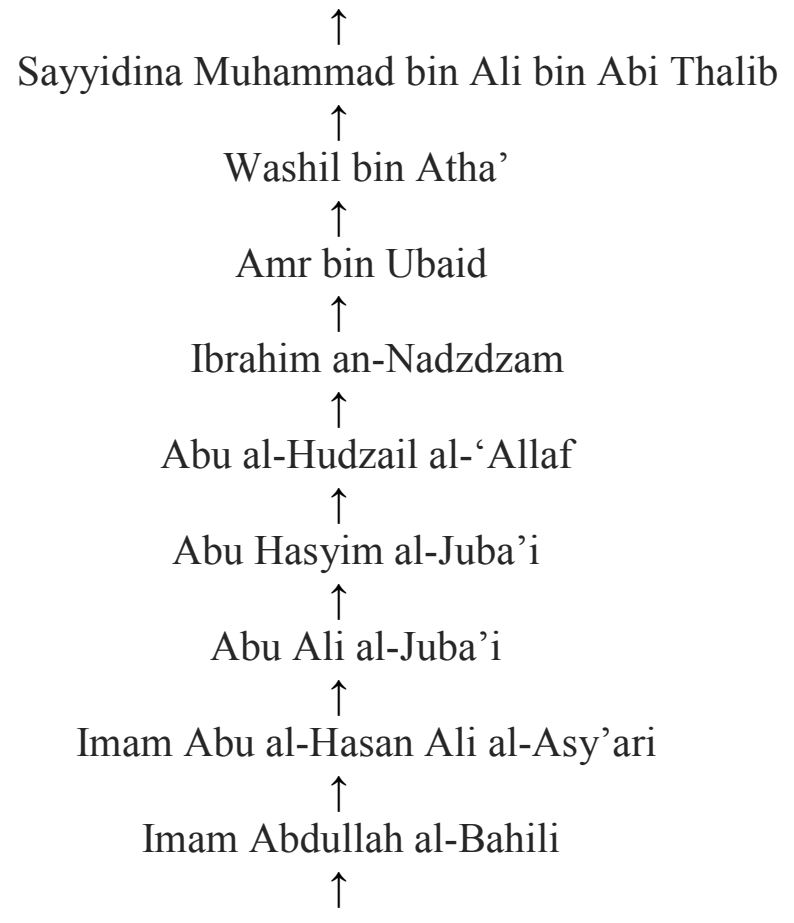

21 | TamaddunVol. 7 , No. 0I, Juli 2019 
Imam Abubakar al-Baqillani

$\uparrow$

Imam Abdul Malik al-Haramain al-Juwaini

Hujjatul Islam Abu Hamid Muhammad al-Ghozali

Imam Abdul Karim asy-Syahrastani
$\uparrow$
Imam Muhammad bin Umar Fakhrurrazi
$\uparrow$
Imam 'Abduddin al-'Iji.
$\uparrow$
Imam Abdullah as-Sanusi
$\uparrow$
Imam Ibrahim al-Baijuri
$\uparrow$
Imam Ahmad ad-Dasuqi
$\uparrow$
and Zaini Dahlan—Syekh Ahmad Khatib Sambas

Sayyid Ahmad Zaini Dahlan punya murid Syaikh Nawawi al-Bantani dan Syekh Mahfud Termas, sementara Syaikh Nawawi al-Bantani dan Syekh Mahfud Termas guru dari KH. Kholil Bangkalan Madura. KH. Kholil Bangkalan Madura adalah guru dari KH. Hasyim Asy’ari, KH. Abbas, KH. Amin Sepuh, KH. Joharul Arifin Balerante. Adapun Syekh Ahmad Khatib Samabas punya murid Syekh Abdul Karim al-Bantani dan Syekh Tolhah Cirebon yang menganut Tarekat Qadiriyah wa Nakhsabandiyah. Syekh Tolhah kemudian punya murid Syekh Abdullah bin Mubarok (Abah Sepuh) yang mendirikan Pesantren Suryalaya di Tasikmalaya.

\section{Jaringan Ulama Pasca Abad ke-19}

Jaringan ulama Cirebon abad ke-19 pada perkembangannya telah banyak mempengaruhi dan merubah kontruksi jaringan yang lebih luas dan kompleks. Pengaruh dari beberapa ulama yang hidup pada abad ke-19 telah berhasil 
melahirkan jaringan ulama baru yang lahir pada abad ke-20. Beberapa ulama yang terlibat dalam jaringan ulama Cirebon abad ke-20 antara lain seperti Kiai Harun Kempek, KH. Hasbullah Winong, Kiai Abdullah Syatori Arjawinangun, Habib Umar Panguragan Arjawinangun, Kiai Sanusi Babakan Ciwaringin, Kiai Cholil Balerante dan ulama-ulama yang lain.

Bisa kita ambil contoh misalnya Kiai Abdullah Syatori yang merupakan murid KH. Ahmad Sobari Kuningan, Kiai Isma'il Babakan Ciwaringin dan juga murid Syekhana Khalil Bangkalan yang merupkan ulama abad 19. Contoh lain misalnya Habib Umar bin Isma'il dan Kiai Cholil Balerante yang merupakan murid dari KH. Abbas Abdul Jamil yang juga merupakan ulama abad 19-20. Kemudian KH. Hasbullah Winong yang merupakan murid dari Kiai Johar Balerante dan para ulama-ulama yang di luar Cirebon misalnya Syekh Abdullah bin Mubarok yang merupakan murid Syekh Tolhhah Kalisapu, kemudian KH. Tubagus Ahmad Bakri atau Mama Sempur yang merupakan murid dari KH. Soleh Zamzami Benda Kerep. Adapun pencapaian-pencapaian yang bisa kita lihat bagaimana peran dan pengaruh dari para ulama pada abad ke-19 kepada para ulama sesudahnya; baik melalui nasab maupun keilmuan sanad tarekat yaitu antara lain seperti Kiai Abdullah Syatori, ia merupakan anak Kiai Sanawi bin Kiai Abdullah, (pendiri Pesantren Dar at-Tauhid Arjawinangun Cirebon), sementara dari jalur ibunya masih keturunan Sunan Gunung Jati. Berikutnya adalah Habib Umar bin Isma'il, ia merupakan ulama pendiri tarekat Syahadatain yang secara nasab juga masih keturunan Sunan Gunung Jati. Sosok ulama berikutnya adalah Kiai Harun, ia merupakan Pendiri Pesantren Kempek pada 1908. Ayahnya bernama Kiai Abdul Jalil yang menikah dengan Nyai Madrawi. Sementara Nyai Madrawi keturunan Sunan Gunung Jati melalui Sultan Komarudin II Keraton Kanoman. 
Keponakan Kiai Harun adalah KH. Hasbullah Winong, ia merupakan pendiri Pesantren Winong pada tahun 1919. KH. Hasbullah adalah putra Ki Qunawi yang tidak lain adalah anak Nyai Madrawi, ibunda Kiai Harun Kempek. Dengan demikian, jaringan nasab ulama abad ke-20 masih terbangun dan banyak melahirkan pondok Pesantren baru sebagai wadah menuangkan intelektualitas dan spiritualitas.

Adapun implikasi secara langsung dari jaringan Ulama abad ke-19 tidak hanya berada di Cirebon, tetapi juga berada di luar Cirebon seperti Syekh Abdullah bin Mubarok yang merupakan murid Syekh Tolhhah Kalisapu yang membangun Pesantren Suryalaya pada awal abad ke- 20, kemudian Tubagus Ahmad Bakri atau Mama Sempur yang merupakan murid dari KH. Soleh Zamzami Benda Kerep yang membangun Pesantren Sempur di Purwakarta Jawa Barat.

\section{Silsilah nasab dan sanad ulama Buntet, Bendakerep, Gedongan dan Balerante}

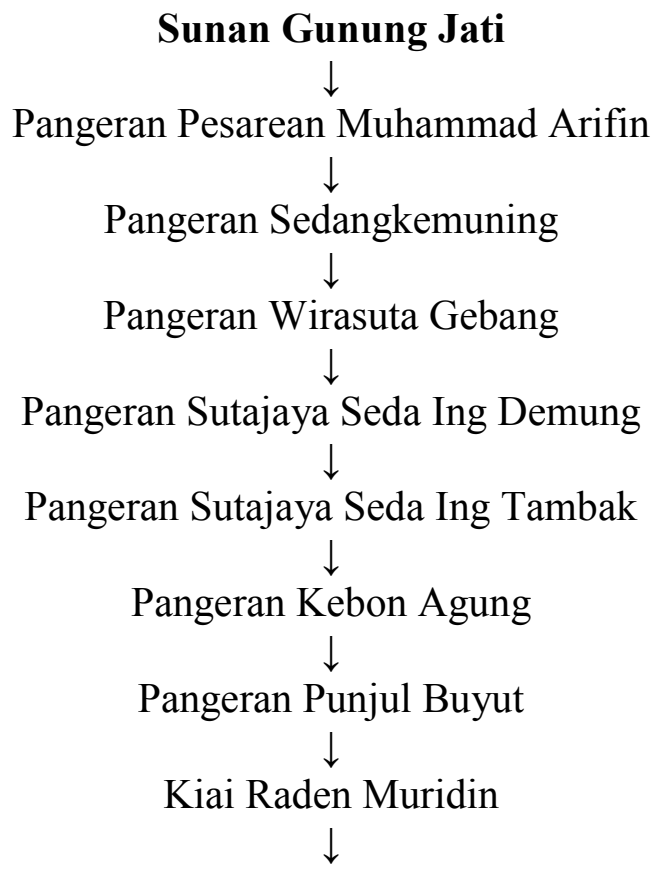

24 | TamaddunVol. 7 , No. 0I, Juli 2019 


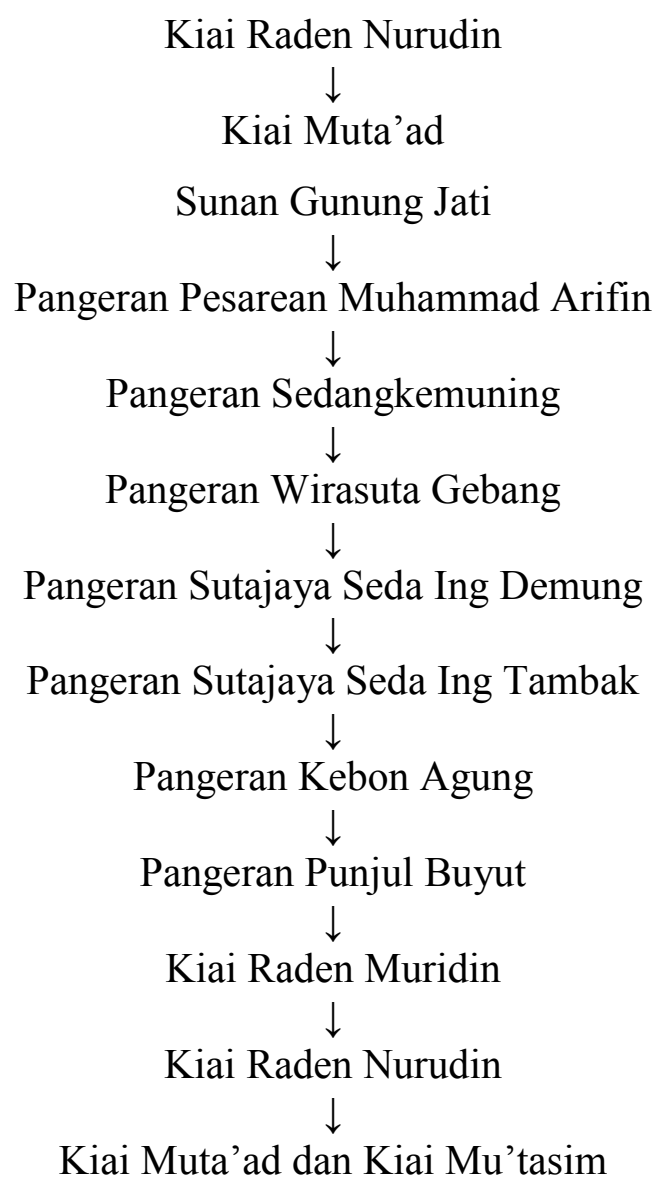

Kiai Muta'ad berputra antara lain : KH. Soleh Zamzami Benda Kerep dan KH. Abdul Jamil Buntet Pesantren, sementara dari jalur KH. Mu'tasim, (saudara Kiai Muta'ad) berputra KH. Said Gedongan. Ketiga pesantren ini, yakni Buntet, Benda Kerep dan Gedongan tidak bisa dilepaskan dari dari sisi keilmuan nasab maupun sanad. KH. Said Gedongan diriwayatkan berguru kepada KH. Abdul Jamil Buntet sekaligus sahabat dari KH. Munawir Krapyak Yogyakarta.

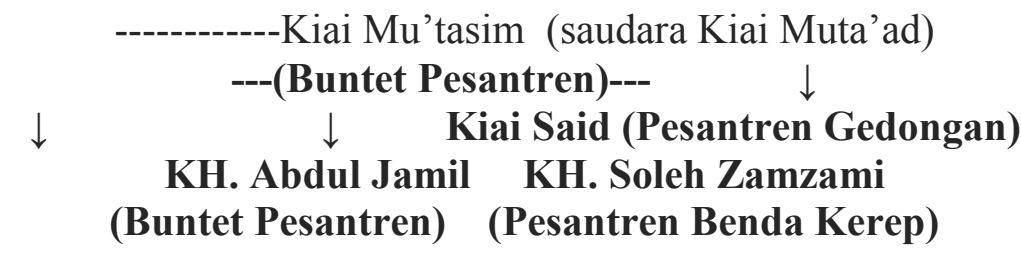

25 | TamaddunVol. 7 , No. 0I, Juli 2019 


\title{
KH. Abbas Abdul Jamil \\ Buntet Pesantren
}

Sosok ulama berikutnya yang juga tidak bisa dipisahkan dari sisi keilmuan nasab dan sanad yang sama-sama dari keturunan Sunan Gunung Jati dan juga pengamal tarekat Syatariyah adalah KH. Johar Balerante. Berikut silsilah nasabnya

\author{
Sunan Gunung Jati \\ $\downarrow$ \\ Pangeran Pesarean Muhammad Arifin \\ Pangeran Sedang Kemuning (Dipati Carbon I) ${ }^{26}$ \\ Pangeran Sidik Jaya Negara \\ Buyut Kamal \\ Buyut Dasim \\ Buyut Puntur/Pantar \\ Kiai Nursijan \\ $\downarrow$ \\ Syekh Romli (Pendiri Pesantren Balerante) ${ }^{27}$ \\ $\downarrow$ \\ Kiai Abdul Majid \\ Kiai Muhammad Joharul Arifin Balerante
}

Silsilah sanad tarekat Syatariyah KH. Johar Balerante

\footnotetext{
${ }^{26}$ Pageran Sedang Kemuning (Dipati Carbon I) menikah dengan Nyai Jangkep Binti Syekh Pasiraga bin Pangeran Ramangkurat Bin Sunan Gunung Jati

${ }^{27}$ Keterangan silsilah ini berasal dari Abah Anom Kusumajati , Pondok Pesantren Balerante
}

26 | TamaddunVol. 7 , No. OI, Juli 2019 
Nabi Muhammad saw

$\uparrow$

Ali r.a.

$\uparrow$

Husain

$\uparrow$

Zainal Abidin

Muhammad Bakir

$\uparrow$

Ja ${ }^{e e}$ far Sadiq

Abi Yazid al-Bustami

$\stackrel{\uparrow}{\text { Magrabi }}$

$\uparrow$

A rabi

$\uparrow$

Mudaffar

$\uparrow$

Abu Hasan al-Harqani

$\uparrow$

Hadaqali

$\uparrow$

Muhammad Asyiq

$\uparrow$

Muhammad Arif

Abd Allah Syatari

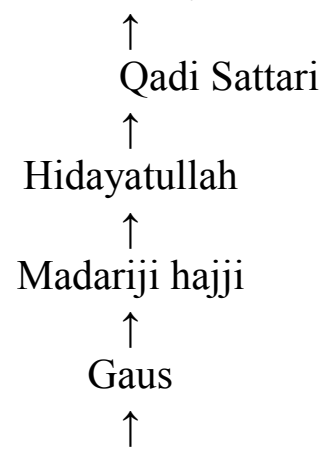

27 | TamaddunVol. 7 , No. OI, Juli 2019 


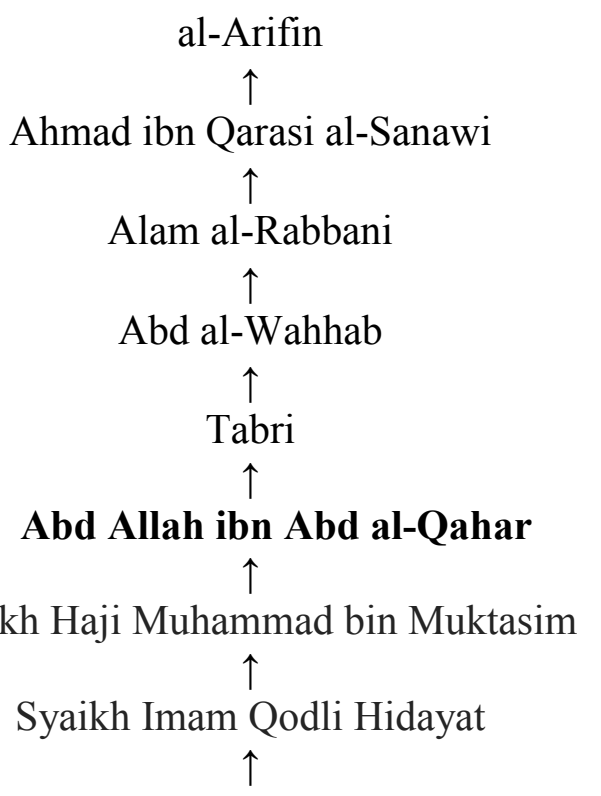

Pangeran Syaikh Muhammad Shofiyyudin Kanoman $\uparrow$

Pangeran Syaikh Muhammad Arifudin Bratawireja Kaprabonan (mursyid 18381878)

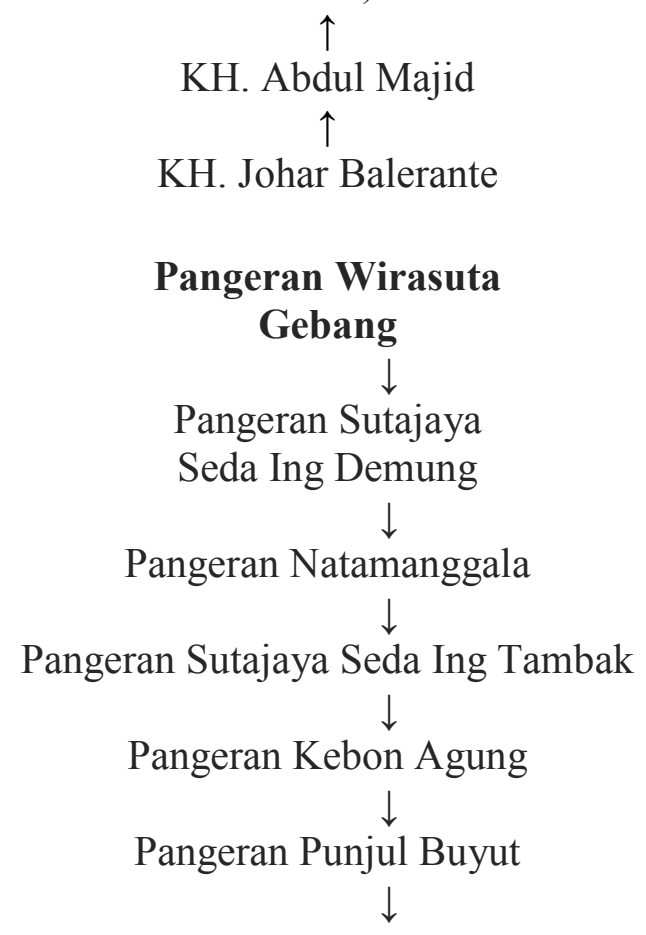

28 | TamaddunVol. 7 , No. OI, Juli 2019 


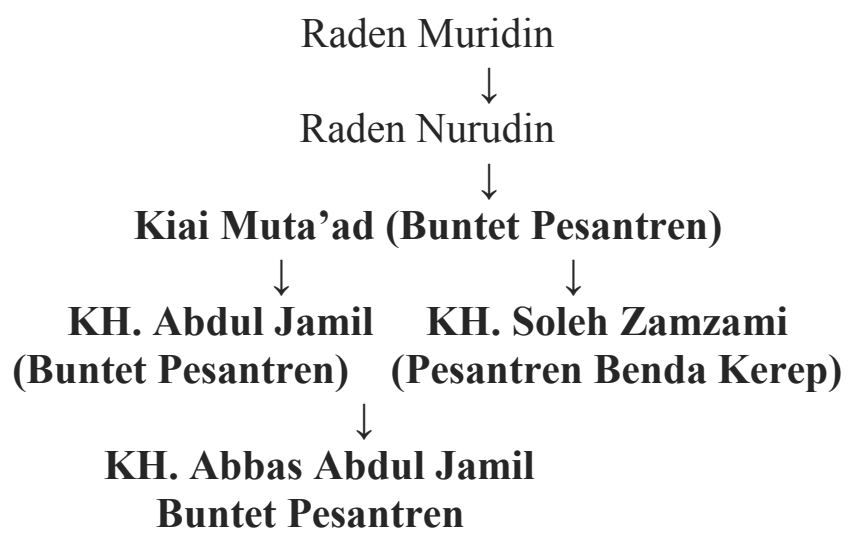

Diantara murid-murid KH. Johar Balerante yang melanjutkan perjuangan beliau adalah K.H. Amin Sepuh, Babakan Ciwaringin, K.H. Hasbullah Winong, K.H. Habib Syeikh Jagasatru, K.H. Syatori Arjawinangun, K.H. Abdullah Marageni Tegalgubug dan ulama-ulama yang lain. Para murid-murid KH. Johar itulah yang kemudian melanjutkan jaringan ulama Cirebon pada abad 20. Bahkan KH. Abbas Abdul Jamil pun pernah belajar kepada KH. Johar Balerante.

Dengan demikian, ketersambungan nasab dan sanad KH. Johar Balerante dan KH. Abbas Abdul Jamil sangat jelas kaitanya dengan melihat silsilah KH. Abbas bin KH. Abdul Jamil, adik dari KH. Soleh Zamzami Benda Kerep sekaligus saudara sepupu KH. Said Gedongan. Adapun murid-murid KH. Abbas yang kelak melanjutkan jaringan ulama abad 20 antara lain : KH. Tubagus Mansur Ma'mun, seorang Qari terkenal pada masanya, KH. Amin Iskandar, Kedubes RI untuk Irak, Profesor KH. Ibrahim Hussein, yang pernah menjadi Rektor IAIN Palembang, Habib Umar bin Isma'il, mursyid pertama tarekat Syahadatain, KH. Abdul Halim Luwimunding Majalengka dan beberapa ulama-ulama yang lain.

\section{PENUTUP}

Sederet nama-nama ulama yang kemudian membangun pondok pesantren dan mempunyai pengaruh yang kuat di wilayahnya masing-masing, semuanya tidak 
lepas dari adanya jaringan ulama yang masih terhubung antara ulama sebelumnya dan sesudahnya abad ke-19. Pengaruh yang ditimbulkan tidak lepas dari ajaran, doktrin dan pola komunikasi yang mempengaruhi prinsip-prinsip dalam berpikir dan bersikap bahkan membentuk karakter melalui ajaran dari guru-guru mereka.

Ulama-ulama dalam jaringan tersebut pada intinya masih tetap terhubung antara satu dengan lainnya; baik melalui silsilah nasab maupun berdasarkan keilmuan berdasarkan sanad tarekat atau keilmuan Islam lainnya untuk tetap melestarikan ajaran Islam sebagai rahmatan lil 'alamiin.

\section{DAFTAR PUSTAKA}

\section{A. BUKU-BUKU}

Aziz, Munawar.Pahlawan Santri, Tulang Punggung Pergerakan Nasional. Ciputat Tangerang: Pustaka Kompas. 2016

Choirul Fuad dkk.Ensiklopedi Pemuka Agama Nusantara. Jakarta: Puslitbang Lektur dan Khazanah Keagamaan Badan Litbang dan Diklat Kementrian Agama RI. 2016

Irianto, Bambang. Teks Klasik Keagamaan Sulawesi dan Cirebon.Jakarta: Puslitbang Lektur dan Khazanah Keagamaan Badan Litbang dan Diklat Kementrian Agama RI. 2013 
Irianto, Bambang dan Ki Tarka Sutaraharja.Babad Cirebon Carub Kandha Naskah Tangkil. Yogyakarta: CV Budi Utama. 2012

Sujana, T.D.Naskah Negara Kreta Bhumi Sarga III Alih Bahasa dan Aksara.Cirebon:Pustaka Keraton Kanoman Kidung Rara Roga. Cirebon: Pustaka Keraton Kanoman. 24 Oktober 1987

Suprapto, Bibit.Ensiklopedi Ulama Nusantara Riwayat Hidup, Karya dan Sejarah Perjuangan 157 Ulama Nusantara. Jakarta: Gelegar Media Indonesia. 2010

Putri, Yulia Eka, dkk. Masjid Kuno Cirebon. Bandung: Dinas Pariwisata dan Kebudayaan Provinsi Jawa Barat. 2015

Amin, Zamzami. Sejarah Pesantren Babakan Ciwaringin dan Perang NasionalKedondong 1802-1919. Bandung: Humaniora. 2015

Zaeni Hasan, Ahmad. Perlawanan Dari Tanah Pengasingan. Jakarta: Elsas. 2000

\section{B. SKRIPSI DAN HASIL PENELITIAN}

Basit, Abdul. Skripsi. Tarekat Syattariyah (Studi Naskah Ratu Raja Fatimah di Keraton Cirebon). Cirebon: Departemen Agama Islam Republik Indonesia IAIN Syekh Nujati Cirebon. 2014

el-Mawa, Mahrus.Melting Pot Islam Nusantara Melalui Tarekat: Studi Kasus Silsilah Tarekat Syatariyah di Cirebon. 05 Juli 2018

Hamdan. Skripsi.Peran Kyai Haji Siradjur Rosyidin (Abah Mutawally) 1819-1953 Dalam Menyebarkan Dakwah Islam Di Kuningan. Cirebon: Jurusan Sejarah Peradaban Islam IAIN Syekh Nurjati Cirebon. 2017

Eli Fatihah. Skripsi. Studi Living Quran: Penggunaan al-Quran Sebagai Media Istikharah di Pesantren al-Ishlah Sidamulya Astanajapura Cirebon. Cirebon: Jurusan Ilmu al-Quran dan Tafsir IAIN Syekh Nurjati Cirebon. 2017 
Zulfa Ahmad. Pdf. Perhajian di abad 19 dan Awal Abad 20 Serta Pengaruhnya Terhadap Pendidikan di Indonesia. e-journal.iainjambi.ac.id. diunduh pada Minggu 4 Juni 2017 pukul 22.00.

C. MAKALAH-MAKALAH

Irianto, Bambang.Makna Simbolik Batik Keraton Cirebon. 2009

Sunyoto, Agus. Buletin Harokah.Melacak Paham Gerakan Islam Trans Nasional. Lirboyo Jawa Timur: Jamiyyah Syubbaniyyah Pusat Keluarga Besar Santri Jawa Barat. 2014

Suriaman, Maman.Perkembangan Pesantren di Wilayah Cirebon dalam Perspektif Sejarah Pendidikan Nasional. Makalah disajikan dalam acara Gotrasawala pada 24 Januari 1990

\section{INTERNET}

El-Mawa, Mahrus. http://syattariyah.blogspot .co.id/2012/05 diunduh pada 3 Juni 2016

Nugraha, Didin. http://tnnujabar.or.id/jejak-pesantren-tatar-sunda-prakemerdekaankabupaten-kuningan-dan-majalengka/ diunduh pada 8 Januari 2019 pukul 10.30 